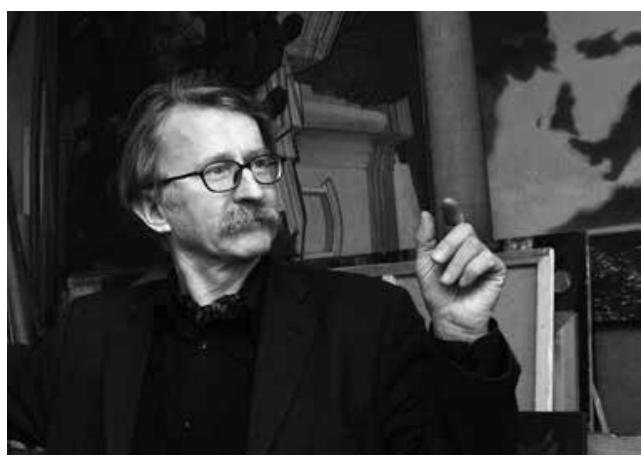

$$
\begin{aligned}
& \text { Tapyba } \\
& \text { Painting }
\end{aligned}
$$

PRANAS GRIUŠYS

\title{
DAILININKAS PRANAS GRIUŠYS
}

Pranas Griušys gimė 1955 m. Klaipėdos rajono Medsėdžių kaime. Dailę studijavo 1976-1982 m. Vilniuje, Valstybiniame dailès institute (dabar - Vilniaus dailès akademija) ir igijo dailininko tapytojo bei pedagogo specialybę. Ittakingiausi jam dėstytojai institute buvo Arvydas Šaltenis, Algimantas Švejgžda, Vincentas Gečas. Jo kolegos ir bendrakursiai: Šarūnas Sauka, Vygantas Paukštė, Audronė Petrašiūnaiè, Eglè Velaniškytė šiandien taip pat gerai žinomi Lietuvos dailininkai. Po studijų P. Griušys persikèlè gyventi i Kauną ir tolesnę kūrybinę veiklą derino su pedagoginiu darbu čia įsikūrusiame Vilniaus dailès akademijos padalinyje. Einamos pareigos keitėsi: nuo 1982 m. dirbo dèstytoju, 1988-1989 m. buvo Dailès pagrindu katedros vedèjas, 1989-1993 m. - Pramoninès dailès fakulteto dekanas, nuo 2004 m. - profesorius. Dailininkas nuo 1982 m. aktyviai dalyvauja parodose Lietuvoje ir užsienyje, yra surengęs personalinių parodų, pelnęs įvairių apdovanojimų, stipendijų (TSRS dailininkų sąjungos stipendija (1985-1987), Lietuvos Respublikos aukščiausio laipsnio valstybès stipendija (1997-1998). Jo kūrinių, pristatomų tarptautinei publikai, geografija išties plati: Maskva (1987), Kylis (1987), Liuksenburgas (1988), Bolonija (1988), Budapeštas (1989), Ryga (1997), Dortmundas (1999), Dublinas (2001), Krokuva (2002), Pekinas (2003) ir kt. Dailininko kūrinių turi įsigijęs nacionalinis M. K. Čiurlionio dailès muziejus, Lietuvos kultūros ministerija, Vilniaus dailès muziejus, Tretjakovo galerija bei privatūs asmenys Lietuvoje ir užsienyje. Nuo 1988 m. jis yra Lietuvos dailininkų sąjungos narys.

P. Griušio kūrybos stilistikai būdingi postmodernizmo, fotorealizmo, hiperrealizmo principai. ! savo kūrinius jis mėgsta integruoti fotografijas, pasitelkti senųjų tapybos meistrų kūrybines parafrazes, panaudoti lengvo humoro elementų, atrasti netikètą žiūros tašką. Dailininko plètojamų temų ratas gana platus: portretai, peizažiniai motyvai, žanrinès, istorinès ir batalinės scenos, kurių ribos maišosi ir susipina. Batalinès scenos igauna žanriškumo aspektų, buitinės situacijos siejamos su netikėtom kultūrinėm reikšmėm, o portretai gali būti susieti su praeities meno citatomis. Šioje žanrinèje įvairovèje ypatingą vietą užima istorinès ir batalinės kompozicijos. Nors jų kiekybiškai nèra tiek jau daug, daugiau nei dešimt, vis dèlto savo svarba Lietuvos tapyboje jos užima išskirtinę vietą, todèl yra vertos didesnio dèmesio bei išsamaus pristatymo.

Doc. dr. Aušriné Kulvietytė-Cemnolonskė Vytauto Didžiojo universitetas

RAKTAŽODŽıAl: P. Griušys, tapyba, VDA Kauno fakultetas, postmodernizmas, fotorealizmas.

KEY WORDS: P. Griušys, painting, Kaunas faculty of Vilnius Academy of Arts, postmdernism; photorealism. 


\section{Artist Pranas Griušys}

Pranas Griušys was born in 1955 in the village of Medsèdžiai (Klaipèda district). In 1976-1982 he studied art in The State Art Institute of the Soviet Socialist Republic of Lithuania (now Vilnius Academy of Arts). He obtained an artist painter and teacher specialty. Arvydas Šaltenis, Algimantas Švegžda, Vincentas Gečas were his most important professors at the Institute. The currently well-known Lithuanian artists as Šarūnas Sauka, Vygantas Paukštè, Audronė Petrašiūnaitė, Eglè Velaniškytė were his study times friends and

P. GRIUŠYS. Autoportretas Istoriniame muziejuje. 1985. Drobè, aliejus. $173 \times 80 \mathrm{~cm}$. Autoriaus nuosavybė

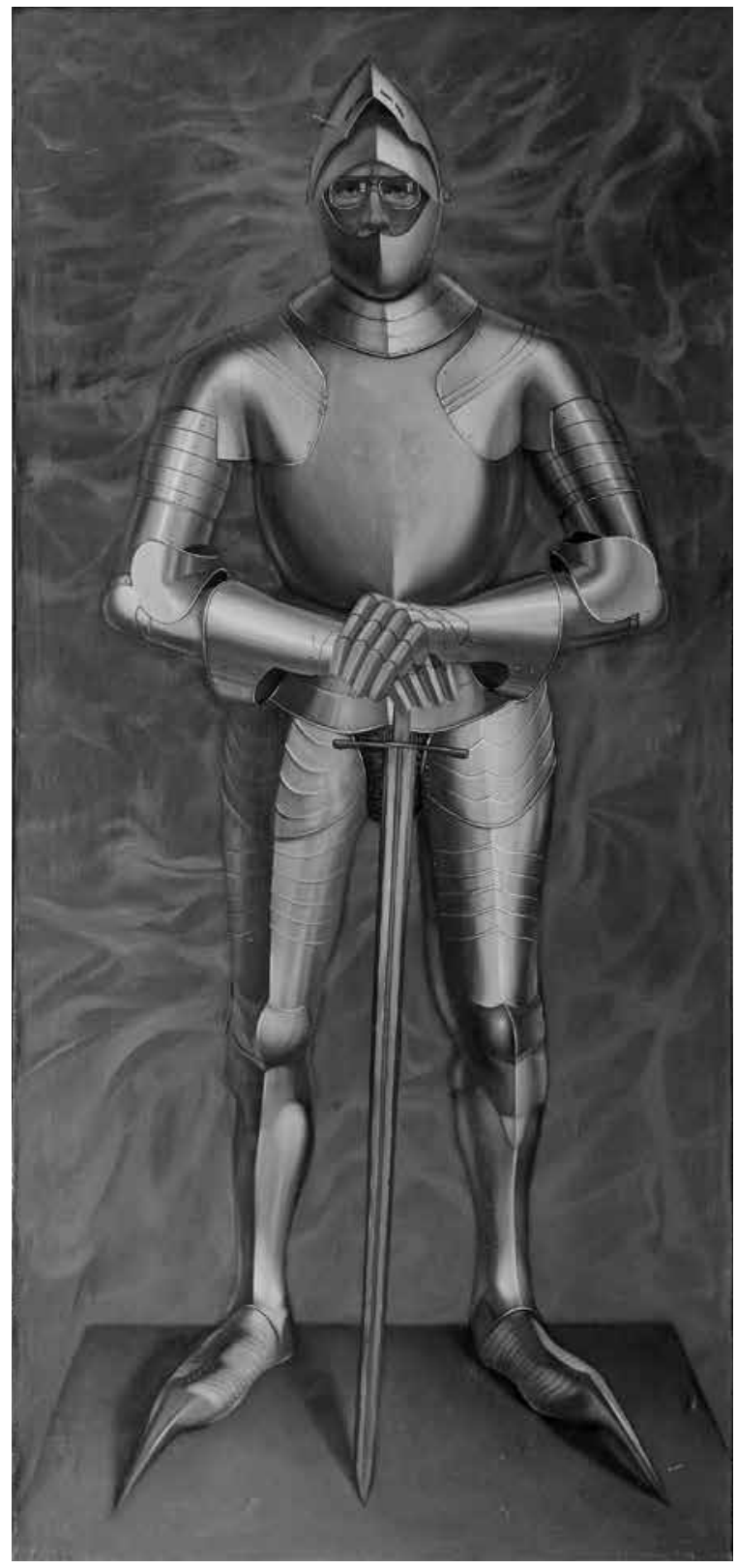

LOGOS 90 


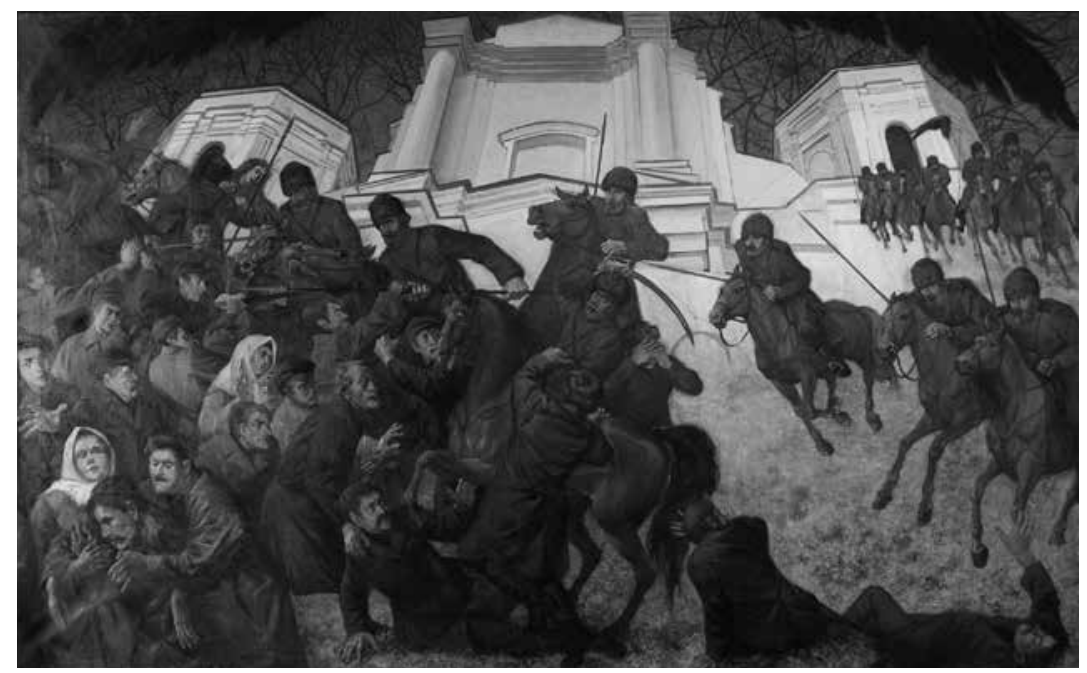

P. GRIUŠYS. Triptikas Kražių skerdynès. II. 1990. Drobė, aliejus. $200 \times 300$ cm. Autoriaus nuosavybè

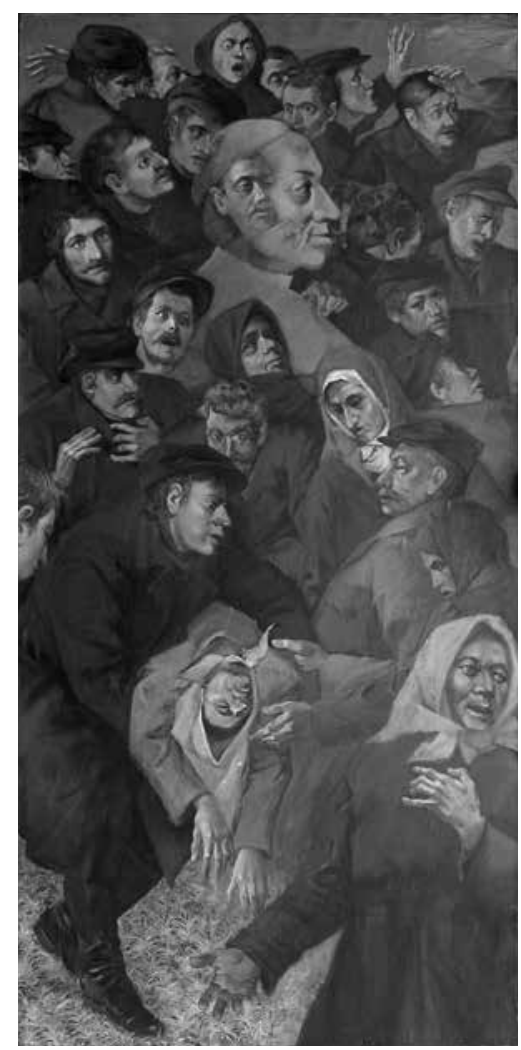

P. GRIUŠYS. Triptikas Kražiu skerdynès. I. 1990. Drobè, aliejus. $180 \times 85 \mathrm{~cm}$. Autoriaus nuosavybè

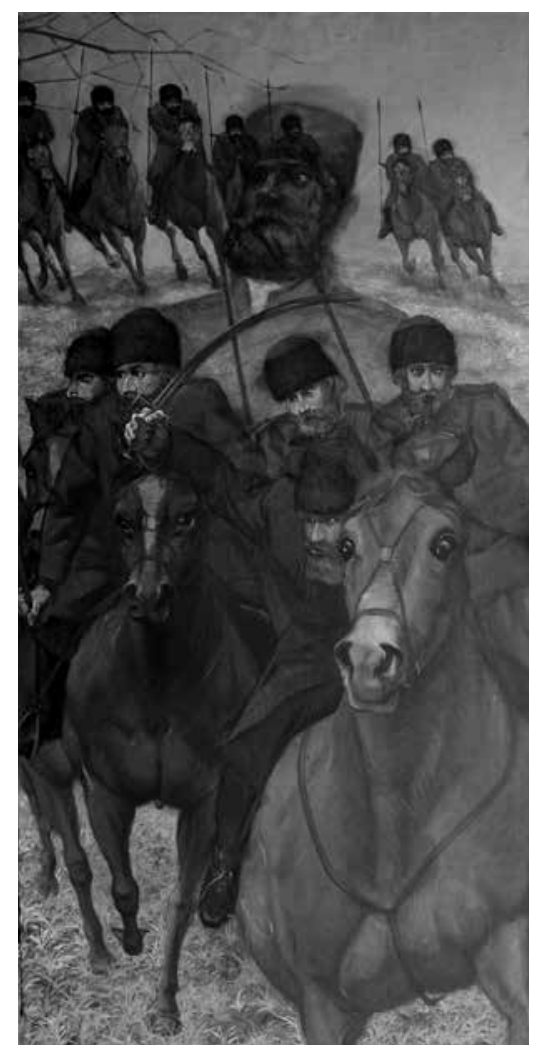

P. GRIUŠYS. Triptikas Kražiu skerdynès. III. 1990. Drobè, aliejus. $180 \times 85 \mathrm{~cm}$. Autoriaus nuosavybè 


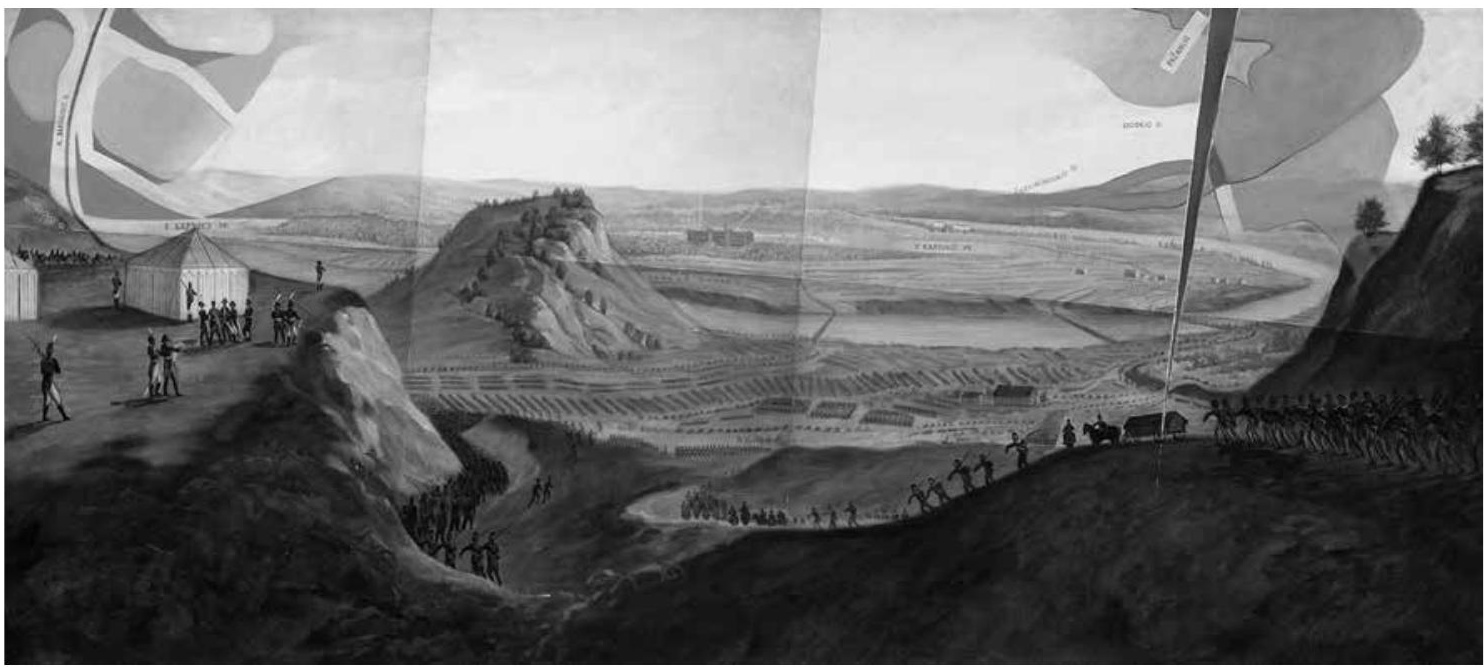

P. GRIUŠYS. 1812 m., Nemunas, Kaunas. 1988. Drobė, aliejus. $111 \times 250,8 \mathrm{~cm}$. Lietuvos dailės muziejus. Inv. Nr. T 8809

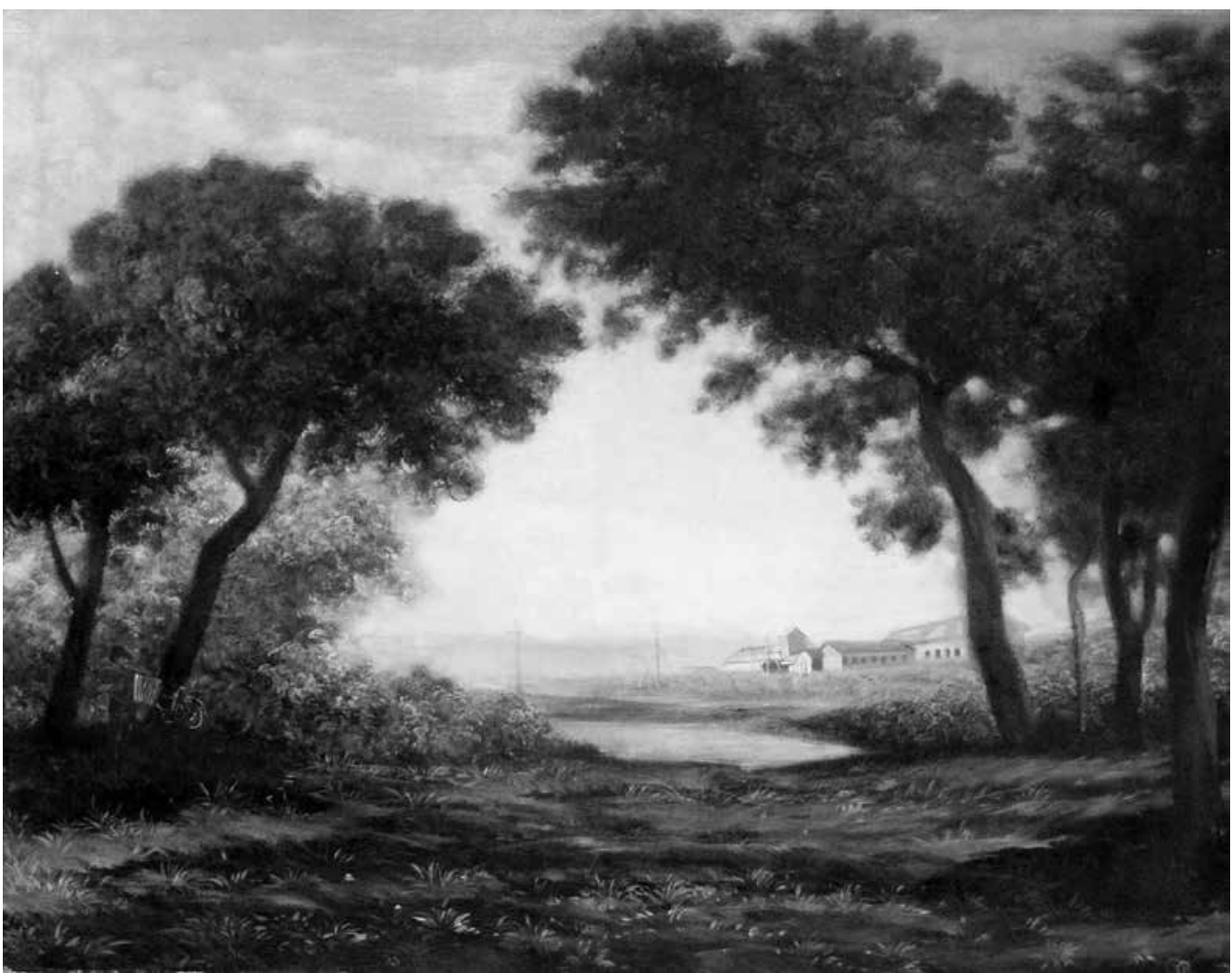

P. GRIUŠYS. Valsiukas fermu griuvèsiams. 2004. Drobė, aliejus. $75 \times 95 \mathrm{~cm}$. Autoriaus nuosavybė 


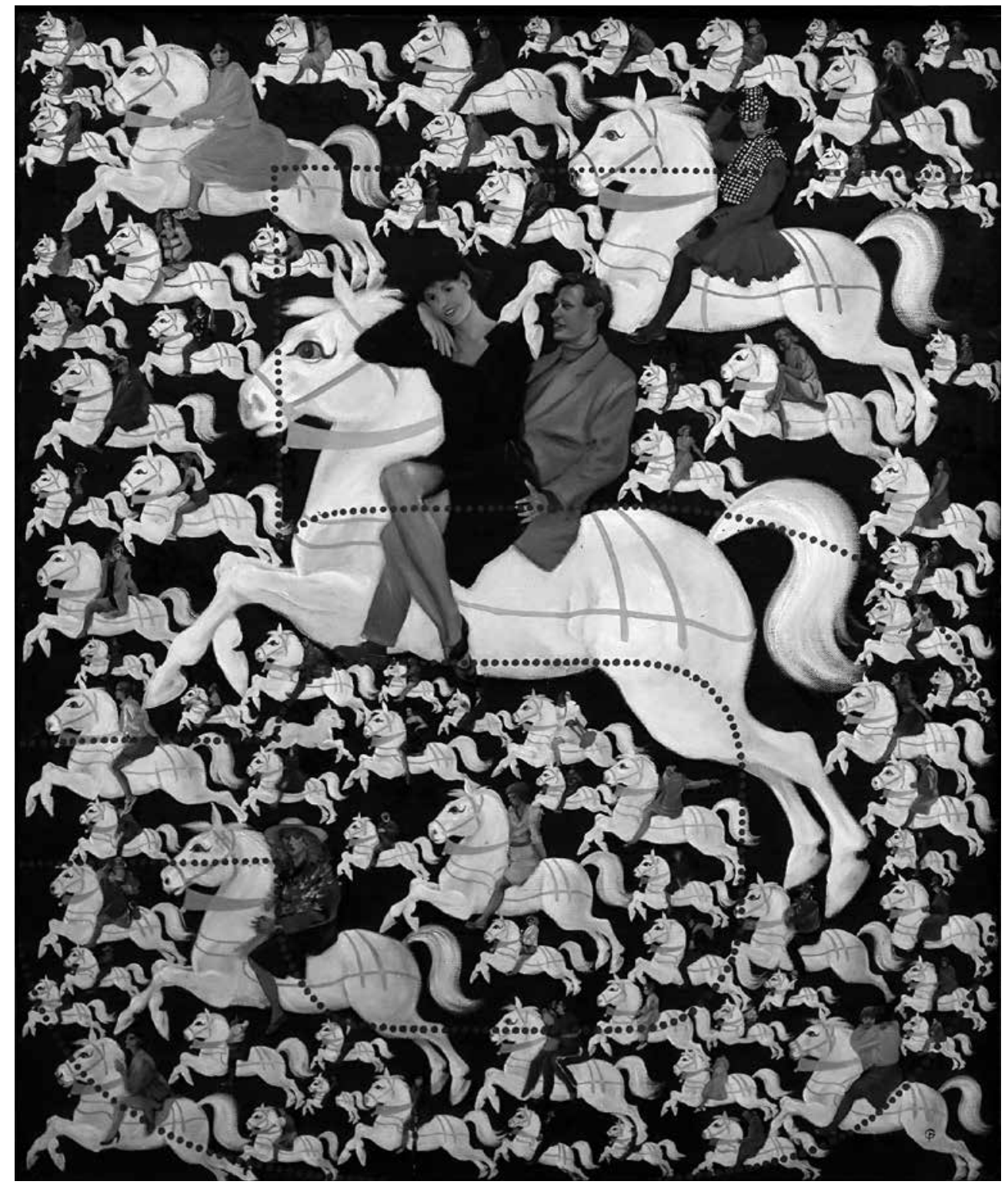

P. GRIUŠYS. Triptikas 500. I. 1993. Drobė, aliejus. Autoriaus nuosavybė 


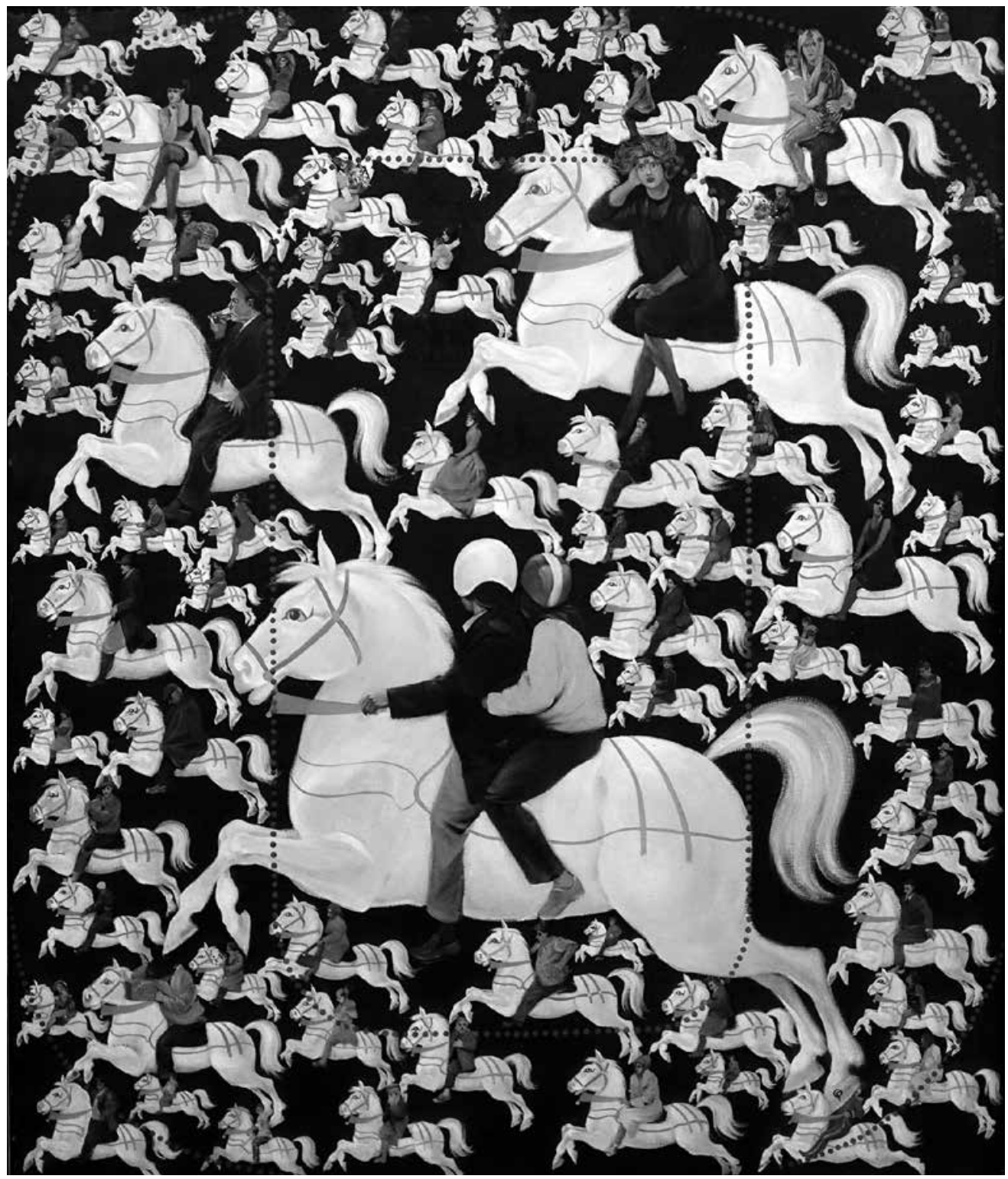

P. GRIUŠYS. Triptikas 500. III. 1993. Drobè, aliejus. Autoriaus nuosavybė 
colleagues. After graduation P. Griušys moved to Kaunas. There his further creative activities were combined with pedagogical work at the department of Vilnius Academy of Arts located in Kaunas. Since this time he took different positions and responsibilities. Since 1982 he worked as a painter-lecturer. In 1988-1989 he was a head of the Department of Art Fundamentals. Then in 1989-1993 he took the position of Dean of the Faculty of Industrial Art. Since 2004 until now he is a professor. Since 1982 the artist actively participates in exhibitions in Lithuania and abroad. Also, he has held personal exhibitions and won various awards, scholarships (The scholarship of USSR Union of Artists (1985-1987), the highest level state scholarship of Republic of Lithuania (1997-1998). His creation, displayed for an international audience, is quite wide geography: Moscow (1987), Kiel (1987), Luxembourg (1988), Bologna (1988), Budapest (1989), Riga (1997), Dortmund (1999), Dublin (2001), Krakow (2002), Beijing (2003) and others. The artist's works are owned by M. K. Čiurlionis National Museum of Arts, Lithuanian Ministry of Culture, Vilnius Art Museum, Tretyakov Gallery and private persons in Lithuania and abroad. Since 1988 he is a member of the Lithuanian Artists' Association.

P. Griušys creative style includes principles of postmodernism, photorealism, hyperrealism. In works he likes to integrate photographs, to use creative paraphrases of the old masters painting, to enter a delicate humorous elements and to discover unexpected viewpoints. The themes of his creation are varied and quite broad. He likes portraits, landscape and genre motifs, historical and battle scenes that lack strict limits. Different genres are intertwined. Battle scenes take aspects of genre painting; daily life situations are associated with unexpected cultural values; and portraits can be combined with artistic citations from art history. In this genre diversity historical and battle compositions occupy an exceptional place. Even though their number is small, over ten, their importance in Lithuanian painting takes a special place. They deserve more attention and comprehensive presentation.

Assoc. Prof. Dr. Aušrinè Kulvietytè-Cemnolonskè, Vytautas Magnus University

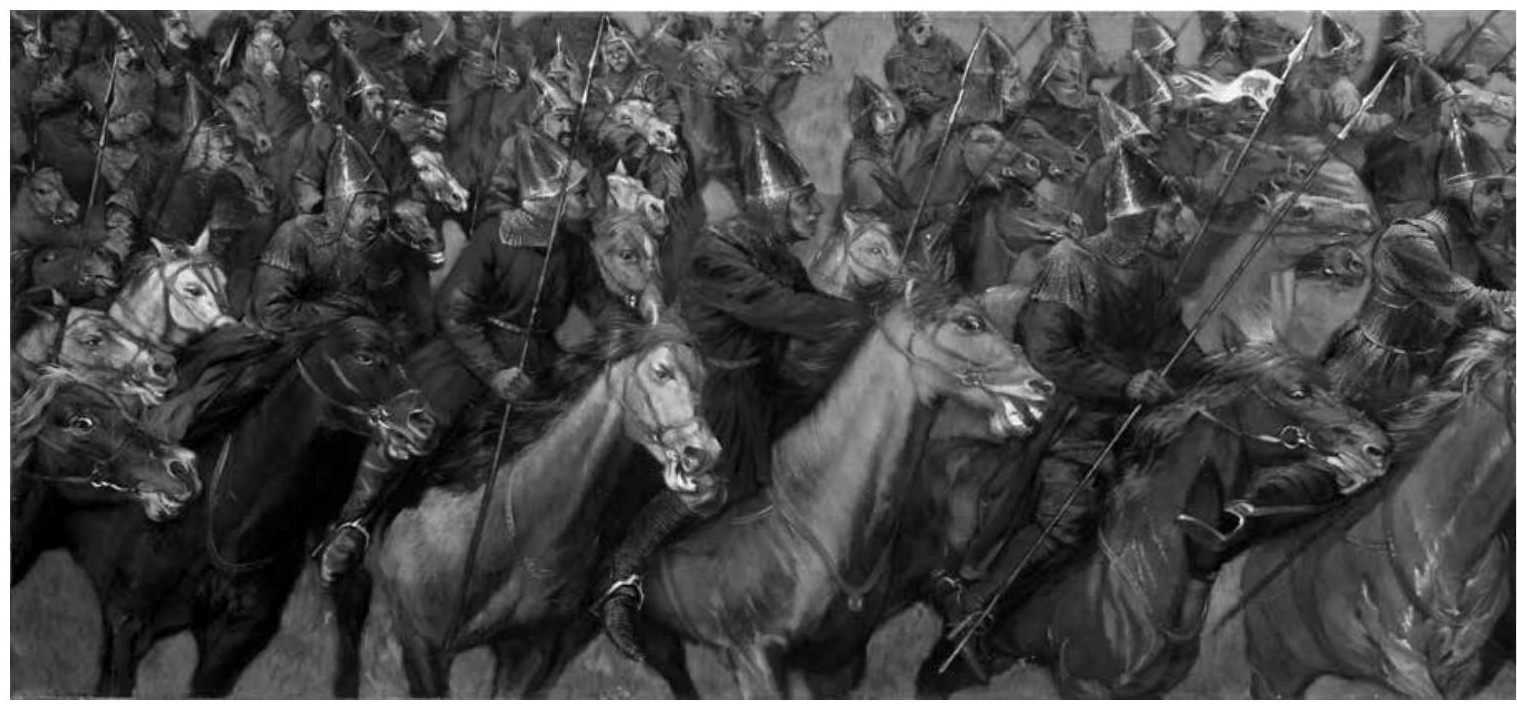

P. GRIUŠYS. Durbės mūšis. III. 2003. Drobè, aliejus. 80 × 206 cm. Autoriaus nuosavybė 


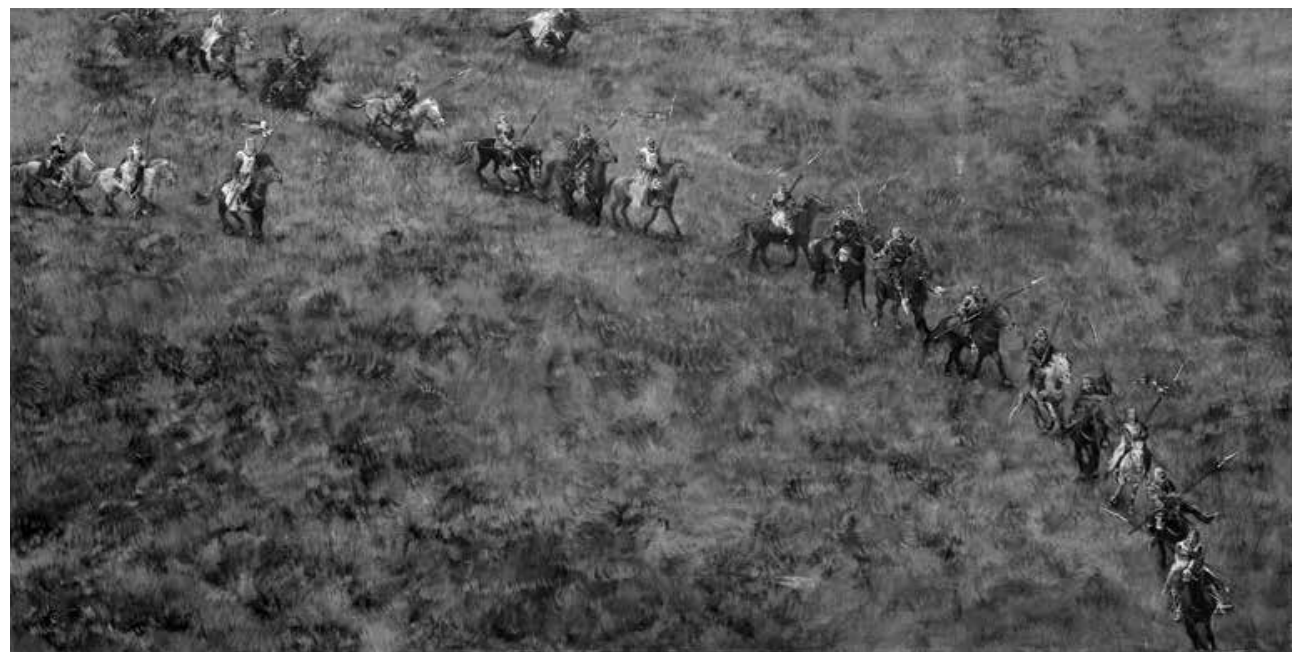

\section{P. GRIUŠYS}

Durbès mūšis. I.

2003. Drobè, aliejus.

$140 \times 206 \mathrm{~cm}$.

Autoriaus nuosavybė
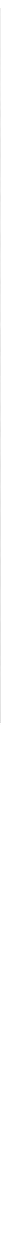

P. GRIUŠYS. Durbės mūšis. II. 2003. Drobė, aliejus. $90 \times 149$ cm. Autoriaus nuosavybė 